\title{
KINETIC MODELLING AND HALF LIFE STUDY OF ADSORPTIVE BIOREMEDIATION OF SOIL ARTIFICIALLY CONTAMINATED WITH BONNY LIGHT CRUDE OIL
}

\author{
Samuel Enahoro Agarry ${ }^{1}$, Kigho Moses Oghenejoboh' ${ }^{1}$, Bamidele Ogbe Solomon ${ }^{2}$ \\ 1 Biochemical and Bioenvironmental Engineering Laboratory, Department of Chemical Engineering, Delta \\ State University, P. M. B. 22, Oleh Campus, Nigeria, e-mail: sam_agarry@yahoo.com; kmoghene@yahoo.com \\ 2 Biochemical Engineering Laboratory, Department of Chemical Engineering, Obafemi Awolowo University, \\ lle-Ife, Nigeria, e-mail: bos77consult@yahoo.com
}

Received: 2015.05.11 Accepted: 2015.06.02 Published: 2015.07.01

\begin{abstract}
In this study, comparative potential effects of commercial activated carbon (CAC) and plantain peel-derived biochar (PPBC) of different particle sizes and dosage to stimulate petroleum hydrocarbon biodegradation in soil were investigated. Microcosms containing soil were spiked with weathered Bonny light crude oil (WBLCO) $(10 \% \mathrm{w} / \mathrm{w})$ and amended with different particle sizes $(0.02,0.07$ and $0.48 \mathrm{~mm})$ and dosage (20, 30 and $40 \mathrm{~g}$ ) of CAC and PPBC, respectively. The bioremediation experiments were carried out for a period of 28 days under laboratory conditions. The results showed that there was a positive relationship between the rate of petroleum hydrocarbons reduction and presence of the CAC and PPBC in crude oil contaminated soil microcosms. The WBLCO biodegradation data fitted well to the first-order kinetic model. The model revealed that WBLCO contaminated-soil microcosms amended with CAC and PPBC had higher biodegradation rate constants $(k)$ as well as lower half-life times $\left(t_{1 / 2}\right)$ than unamended soil (natural attenuation) remediation system. The rate constants increased while half-life times decreased with decreased particle size and increased dosage of amendment agents. ANOVA statistical analysis revealed that WBLCO biodegradation in soil was significantly $(p=0.05)$ influenced by the addition of CAC and biochar amendment agents, respectively. However, Tukey's post hoc test (at $p=0.05$ ) showed that there was no significant difference in the bioremediation efficiency of CAC and PPBC. Thus, amendment of soils with biochar has the potential to be an inexpensive, efficient, environmentally friendly and relatively novel strategy to mitigate organic compound-contaminated soil.
\end{abstract}

Keywords: activated carbon, biochar, biodegradation, crude oil, first-order kinetics.

\section{INTRODUCTION}

Crude oil is an extremely complex mixture of aliphatic and aromatic hydrocarbons, including volatile components of gasoline, petrol, kerosene, lubricating oil and solid asphaltene residues. Crude oil causes a variety of risks when released into the environment. It is physically, chemically and biologically harmful to soil because of the presence of many toxic compounds, such as polycyclic aromatic hydrocarbons, benzene and its substituted and cyclo alkane rings, in relatively high concentrations. This oil can cause chronic sub-acute toxicological effect (reduced growth and reproduction, poor health, low recruitment rates), which can alter population dynamics and disrupt tropic interactions and the structure of natural communities within ecosystems [Bejarano and Michel, 2010].

The remediation processes leading to the eventual removal of these petroleum hydrocarbons from the environment involve the trio of physical, chemical and biological alternatives [Okoh, 2006]. The Physical and chemical meth- 
ods are the most widely used procedures for clean-up [Ikhajiagbe and Anoliefo, 2011]. However, the physicochemical methods have their limitations [Less and Senior, 1995; Vidali, 2001] as they do not always result in complete neutralization of pollutants [Yerushalmi et al., 2003]. As a result of this limitation, great deals of literature have reported that bioremediation methods are alternatives and/or supplements to these methods. This is because of their cost effectiveness, environmental friendliness, simplicity in technology and conservation of soil texture and characteristics [Mandri and Lin, 2007; Adams and GuzmánOsorio, 2008; Fouépé et al., 2009]; however, the method requires longer treatment time [Agarry and Ogunleye, 2012]. Despite the great advantages of bioremediation, this approach is now used in only about $5 \%$ of all soil treatments [Vasilyeva et al., 2006]. One of the reasons for the longer treatment time of soil bioremediation is the high toxicity of chemical contaminants to microbes and plants. This phenomenon often restricts its use for highly contaminated soils. Amendment of soil with natural adsorbents can help to overcome this problem [Vasilyeva et al., 2006]. In many natural ecosystems a combination of biological and adsorption processes is a common phenomenon. Organic pollutants discharges from industries are removed from the environment due to simultaneous adsorption and biodegradation (Orshansky and Narkis, 1997). Thus, combined method such as simultaneous adsorption and biodegradation is now gaining importance [Agarry and Aremu, 2012].

Activated carbon (AC) addition is currently being investigated as in situ technology to remediate polluted sediments and soil [Ghosh et al., 2011; Meynet et al., 2012]. Activated or nonactivated charcoals have been shown to reduce phytotoxicity of many herbicide residues and other chemicals in agricultural soils [Strek et al., 1981; Mukhin et al., 1995], reduce hydrophobic organic pollutant leaching [Hale et al., 2012], pollutant loss to the atmosphere [Bushnaf et al., 2011], and uptake from soil by plants [Vasilyeva et al., 2010; Jakob et al., 2012], and earthworms [Langlois et al., 2011]. However, replacing coalderived activated carbon with biochar is motivated by the successful use of coal-derived activated charcoals for the in-situ sequestration of hydrophobic organic compounds (HOCs) [Ghosh et al., 2011] and thus would reduce economic costs and improve the sustainability of remediation efforts [Sparrevik et al., 2011].
Biochar is the product of thermal degradation of organic materials in the absence of air (pyrolysis), [Lehmann and Joseph, 2009]. The use of biochar as an amendment for the remediation of contaminated soil [Beesley et al., 2010] has been found to be effective for three basic reasons: (1) it adsorbs and holds metals and organic compounds thereby removing the material from contact with plants, animals and humans; (2) it fosters the introduction of beneficial microbes which also promote remediation; and (3) it improves the overall soil quality and fertility by acting as fertilizer [Glaser et al., 2001; Marris, 2006] as well as other ecosystem services and sequester carbon (C) to mitigate climate change [Lehmann, 2007; Laird, 2008; Sohi et al., 2010]. The observed effects on soil fertility have been explained mainly by a pH increase in acid soils [Van Zwieten et al., 2010] or improved nutrient retention through cation adsorption [Liang et al., 2006]. However, biochar has also been shown to change soil biological community composition and abundance [Neill et al., 2009; Liang et al., 2010].

Biochars have attracted a lot of research within the last years basically with focus on the application of biochars to soils to determine its priming effect on soil organic matter degradation, contribution to soil carbon balance [Solomon et al., 2007; Spokas et al., 2009; Novak et al., 2010; Zimmerman et al., 2011] and its effect on organic chemical leachability and bioavailability [Xu et al., 2012]. However, literature information on the effects of biochar and activated carbon addition on soil microorganisms growth and its subsequent indirect impact on the catabolic activity of petroleum hydrocarbon during mineralization (degradation) is still limited. The main objective of this work was to study and compare the potential effects of commercial activated carbon (CAC) and plantain-peel derived biochar using different particle sizes and dosage on the enhancement of weathered Bonny light crude oil (WBLCO) bioremediation in soil. The bioremediation kinetics of Bonny light crude oil in soil with respect to the $\mathrm{CAC}$ and biochar amended soil as well as the unamended soil was determined and modeled using first-order kinetic model.

\section{MATERIALS AND METHODS}

\section{Collection of samples}

The soil sample used for the study was collected from the top surface soil $(0-15 \mathrm{~cm})$ of an agricultural farm land, Oleh, Nigeria. The soil 
samples were air dried, homogenized, passed through a 2-mm (pore size) sieve and stored in a polythene bag and kept in the laboratory prior to use. The Bonny light crude oil (API, 31.2 and density, $0.8694 \mathrm{~kg} / \mathrm{l}$ ) was obtained from Nigerian National Petroleum Corporation, Port Harcourt, Nigeria. It was weathered by exposure to the atmospheric condition from 10.00 a.m to 4.00 p.m for two weeks with occasional stirring after which it was stored for further use. Plantain peels used for the production of biochar were obtained from restaurants in Oleh, Nigeria. Commercial activated carbon (CAC) was bought from scientific chemical store in Benin, Nigeria.

\section{Characterization of soil sample}

The soil sample was characterized for total carbon (TOC), total nitrogen $(\mathrm{N})$, total phosphorus, moisture content, and $\mathrm{pH}$ according to standard methods. The $\mathrm{pH}$ was determined according to the modified method of McLean (1982); total organic carbon was determined by the modified wet combustion method [Nelson and Sommers, 1982] and total nitrogen was determined by the semimicro-Kjeldhal method [Bremner and Mulvaney, 1982]. Available phosphorus was determined by Brays No.1 method [Olsen and Sommers, 1982] and moisture content was determined by the dry weight method. The total hydrocarbon degrading bacteria (THDB) populations was determined by the vapor phase transfer method [Amanchuckwu et al., 1989]. The physicochemical characterized parameters are presented in Table 1.

\section{Preparation of biochar}

The plantain peels as the precursor material for biochar preparation was well washed with water several times, cut into small sizes, sundried for two weeks and then oven dried at $110{ }^{\circ} \mathrm{C}$ for $3 \mathrm{~h}$.

Table 1. Physical and chemical characteristics of the un-impacted soil

\begin{tabular}{|l|c|}
\hline \multicolumn{1}{|c|}{ Parameters } & Value \\
\hline Total nitrogen $(\%)$ & $0.85 \pm 0.01$ \\
\hline Total carbon (\%) & $1.15 \pm 0.03$ \\
\hline Total organic matter (\%) & $0.68 \pm 0.02$ \\
\hline Available phosphorus (\%) & $0.36 \pm 0.02$ \\
\hline pH & $7.2 \pm 0.2$ \\
\hline Moisture content & $10.4 \pm 0.1$ \\
\hline $\begin{array}{l}\text { Total Hydrocarbon Degrading Bacteria } \\
(\text { THDB) (cfu/g) }\end{array}$ & $23 \pm 1.6 \times 106$ \\
\hline
\end{tabular}

The dried sample was used for black carbon (biochar) preparation. The plantain peel-biochar was prepared at a carbonized temperature of $350{ }^{\circ} \mathrm{C}$ for $5 \mathrm{~h}$ in a pyrolysis furnace for thermal decomposition of the dried sample after which it was cooled to room temperature.

\section{Solid-phase experimental design and soil treatment}

Soil samples $(1 \mathrm{~kg})$ was put into 13 different plastic bins (microcosm) with a volume of about $3 \mathrm{~L}$ and labeled A to $\mathrm{M}$, respectively. The soil in each plastic bins was spiked with $10 \%(\mathrm{w} / \mathrm{w})$ weathered Bonny light crude oil (WBLCO) and thoroughly mixed together to achieve complete artificial contamination. $10 \%$ spiking was adopted in order to achieve severe contamination because above $3 \%$ concentration, oil has been reported to be increasingly deleterious to soil biota and crop growth [Osuji et al., 2005]. The soil in each microcosm A, B and C was correspondingly adjusted by the addition of 20,30 and $40 \mathrm{~g}$ each of biochar having the same particle size $(0.02 \mathrm{~mm})$ while 20 , 30 and $40 \mathrm{~g}$ of commercial activated carbon (CAC) was added to the soil in microcosm $\mathrm{D}, \mathrm{E}$ and $\mathrm{F}$, respectively. In addition, $0.4,0.069$ and $0.02 \mathrm{~mm}$ particle sizes of plantain peel-biochar was added to the soil in microcosm G, H and I, respectively, and the same particle size of $0.4,0.069$ and 0.02 $\mathrm{mm}$ of CAC was added to the soil in microcosm $\mathrm{J}, \mathrm{K}$ and $\mathrm{L}$, respectively. It was assumed that the aforementioned quantities of biochar and CAC applied to the relevant treatment microcosm were well worked to at least $15 \mathrm{~cm}$ depth in each plastic bin. The moisture content was adjusted to $50 \%$ water holding capacity by the addition of sterile distilled water and incubated at room temperature $\left(28 \pm 2{ }^{\circ} \mathrm{C}\right)$. The content of each bin was tilled twice a week for aeration, and the moisture content was maintained at $50 \%$ water holding capacity. Microcosm $\mathrm{M}$ (plastic bin $\mathrm{M}$ ) with soil and weathered crude oil without biochar or CAC (amendment agents) served as control. The experiment was set up in triplicate. In total, 39 microcosms were settled and incubated for four weeks (28 days). Periodic sampling from each plastic bin was carried out at 7-day intervals for 28 days to determine the residual total petroleum hydrocarbon (TPH).

\section{Total petroleum hydrocarbon determination}

The total petroleum hydrocarbon (TPH) content of the soil samples was extracted using sol- 
vent extraction method of Adesodun and Mbagwu (2008). Soil samples (approximately $10 \mathrm{~g}$ ) was taken from each microcosm and put into a $50-\mathrm{ml}$ flask and $20 \mathrm{ml}$ of $\mathrm{n}$-hexane was added. The mixture was shaken vigorously on a magnetic stirrer for 30 minutes to allow the hexane extract the oil from the soil sample. The solution was then filtered using a Whatman filter paper and the liquid phase extract (filtrate) diluted by taking $1 \mathrm{ml}$ of the extract into $50 \mathrm{ml}$ of hexane. The absorbance of this solution was measured spectrophotometrically at a wavelength of $400 \mathrm{~nm} \mathrm{HACH} \mathrm{DR/2010}$ Spectrophotometer using n-hexane as blank. The total petroleum hydrocarbon in soil was estimated with reference to a standard curve derived from fresh crude oil of different concentration diluted with n-hexane. Percent degradation (D) was calculated using the following formula:

$$
\mathrm{D}=\frac{T P H_{i}-T P H_{r}}{T P H_{i}} \times 100
$$

Where $\mathrm{TPH}_{l}$ and $\mathrm{TPH}_{r}$ are the initial and residual TPH concentrations, respectively.

\section{Determination of microbial (total hydrocarbon-degrading bacteria) count}

Quantification of the total hydrocarbon-degrading microorganisms (THDB) present in the soil samples was determined at the beginning of the experiment (time zero) and after 7, 14 and 21 days of remediation time by the pour plate count technique. Soil samples (10 g) was transferred into sterilized Erlenmeyer conical flasks containing $90 \mathrm{ml}$ of sterile $0.9 \%(\mathrm{~m} / \mathrm{v}) \mathrm{NaCl}$ solution and then shaken in a shaker for $15 \mathrm{~min}$ at $150 \mathrm{rpm}$. Samples $(1 \mathrm{~mL})$ were subjected to a serial 10-fold dilution procedure and cultivated in a nutrient agar medium. Three plates were inoculated for each dilution. The plates were incubated at $30{ }^{\circ} \mathrm{C}$ for 48 $\mathrm{h}$ and the number of colony forming units (CFU) was counted in each sample. The results were expressed as colony-forming units per gram of dry soil (CFU/g dry soil). All microbiological counts and experiments were carried out in triplicate.

\section{Bioremediation kinetics}

Kinetic analysis is a key factor for understanding biodegradation process, bioremediation speed measurement and development of efficient clean up for a crude oil contaminated environment. The information on the kinetics of soil bioremediation is of great importance because it characterizes the concentration of the contaminant remaining at any time and permit prediction of the level likely to be present at some future time. Biodegradability of crude oil is usually explained by first order kinetics [Zahed et al., 2011; Agarry et al., 2013] and this is given as in Eq. (2):

$$
C_{t}=C_{o} e^{-k t}
$$

where: $C_{o}-$ the initial TPH content in soil $(\mathrm{mg} / \mathrm{kg})$,

$C_{t}-$ the residual TPH content in soil at time $t,(\mathrm{mg} / \mathrm{kg})$,

$k$ - the biodegradation rate constant $\left(\right.$ day $\left.^{-1}\right)$, $t$ - time (day).

Plotting the logarithm of TPH concentration versus time presents appropriate information about the biodegradation rate.

\section{Estimation of biodegradation half-life times}

The biological half-life is the time taken for a substance to lose half of its amount. Biodegradation half-lives are needed for many applications such as chemical screening [Aronson et al., 2006], environmental fate modeling [Sinkkonan and Paasivirta, 2000] and describing the transformation of pollutants [Matthies et al., 2008]. Biodegradation half-life times $\left(t_{1 / 2}\right)$ are calculated by Eq. (3) [Kuhan and Gupta, 2009]:

$$
t_{1 / 2}=\frac{\ln 2}{k}
$$

where: $k$ - the biodegradation rate constant $\left(\right.$ day $\left.^{-1}\right)$.

The half life model is based on the assumption that the biodegradation rate of hydrocarbons positively correlated with the hydrocarbon pool size in soil [Yeung et al., 1997].

\section{Data analysis}

The data were subjected to one-way analysis of variance (ANOVA) at 5\% probability. Mean of the different treatments were tested for level of significant differences at $p<0.05$ by Tukey (Honestly Significant Difference) test. The data analysis was performed using statistical package for social sciences, version 16.0 (SPSS Inc., Chicago, IL, USA). Tukey's Honestly Significant Difference (HSD) test:

$$
H S D=q \times \sqrt{\frac{M S E}{n}}
$$

where: $q$ - the value from studentized range table; $M S E$ - Mean Square Error from ANOVA table; $n$-number of replicates per treatment. 
Decision: Reject $H_{\mathrm{o}}$ if $\bar{X}_{i}-\bar{X}_{j}>\mathrm{HS}$

Where: $\bar{X}$ - the mean of TPH at different $i^{\text {th }}$ and $j^{\text {th }}$ microcosm treatment, $H_{\mathrm{o}}-$ null hypothesis.

\section{RESULTS AND DISCUSSION}

\section{Removal of total petroleum hydrocarbons}

The level of WBLCO biodegradation in soil amended with CAC of different particle sizes and dosage are shown in Figure 1 (a) and (b), respectively.

Figure 1(a) shows the degradation profile of WBLCO in soil as a function of remediation time for $20 \mathrm{~g}$ of $0.48,0.07$ and $0.02 \mathrm{~mm}$ particle sizes of CAC amendment, respectively (i.e. effect of particle size). Figure 1 revealed that the petroleum hydrocarbon degradation began during the first week of remediation time in all the treatments and slowly continued up to the fourth week (day 28). The TPH correspondingly reduced from 5469,5400 and $5213 \mathrm{mg} / \mathrm{kg}$ soil (day 0) to 3281 , 2697 and $2000 \mathrm{mg} / \mathrm{kg}$ soil (day 28) corresponding to $40 \%, 50.1 \%$ and $61.6 \%$ TPH degradation in soil amended with $0.48,0.07$ and $0.02 \mathrm{~mm}$ particle sizes of CAC, respectively. For the unamended soil (natural attenuation), the TPH reduced from $5481 \mathrm{mg} / \mathrm{kg}$ soil (day 0 ) to $4286 \mathrm{mg} /$ $\mathrm{kg}$ soil (day 28) which corresponds to $21.8 \%$ TPH degradation. These observations indicates that degradation of petroleum hydrocarbons in WBLCO contaminated soil amended with differ- ent particle sizes of CAC increased with decrease in particle size. That is, percent TPH degradation was relatively higher for soil amended with smaller particle size of CAC.

The biodegradation profile of WBLCO in soil as a function of remediation time for $0.48 \mathrm{~mm}$ particle size of 20, 30 and $40 \mathrm{~g}$ of CAC amendment, respectively (i.e. effect of CAC dosage), is shown in Figure 1b. It is seen that the TPH biodegradation began during the first week of remediation time in all the treatments and this slowly continued up to the fourth week (day 28). The TPH reduced correspondingly from 5469, 5387 and 5611 $\mathrm{mg} / \mathrm{kg}$ soil (day 0) to 3281,2653 and $1908 \mathrm{mg} / \mathrm{kg}$ soil (day 28) corresponding to $40 \%, 50.8 \%$ and $66 \% \mathrm{TPH}$ degradation in soil amended with 20 , 30 and $40 \mathrm{~g}$ dosage of CAC, respectively. For the unamended soil (natural attenuation), the TPH reduced from $5481 \mathrm{mg} / \mathrm{kg}$ soil (day 0) to $4286 \mathrm{mg} /$ $\mathrm{kg}$ soil (day 28) which corresponds to $21.8 \% \mathrm{TPH}$ degradation. This observation indicates that degradation of petroleum hydrocarbons in WBLCO contaminated soil amended with different dosage of CAC increased with increase in dosage. That is, percentage degradation of petroleum hydrocarbons was relatively higher for soil amended with higher dosage of CAC. It is seen from Figure $1 \mathrm{a}$ and $1 \mathrm{~b}$ that the soil amendment with CAC generally enhanced the TPH biodegradation in comparison with the unamended contaminated soil (natural attenuation). This observation could be due to the fact that CAC acted as an adsorbent in the soil by allowing the contaminant to be strongly bound to it, thus creating favourable conditions (a)

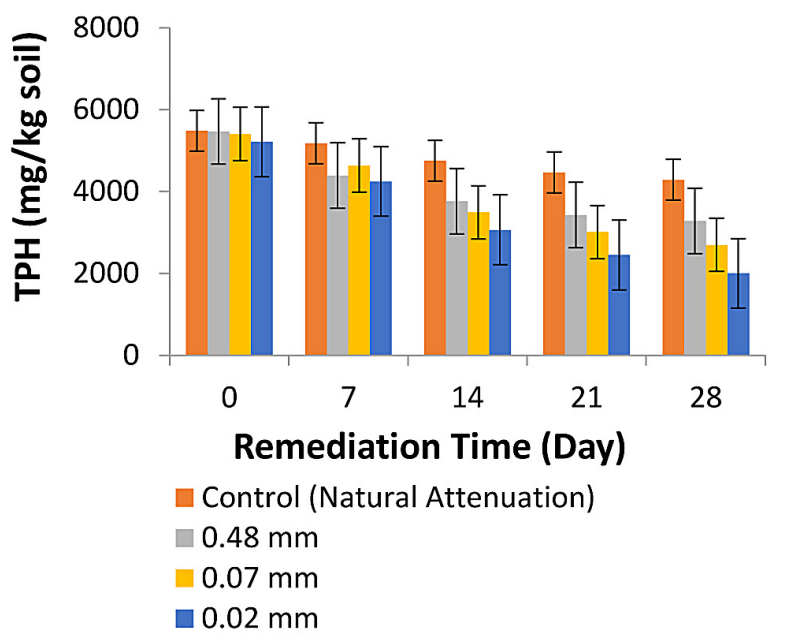

(b)

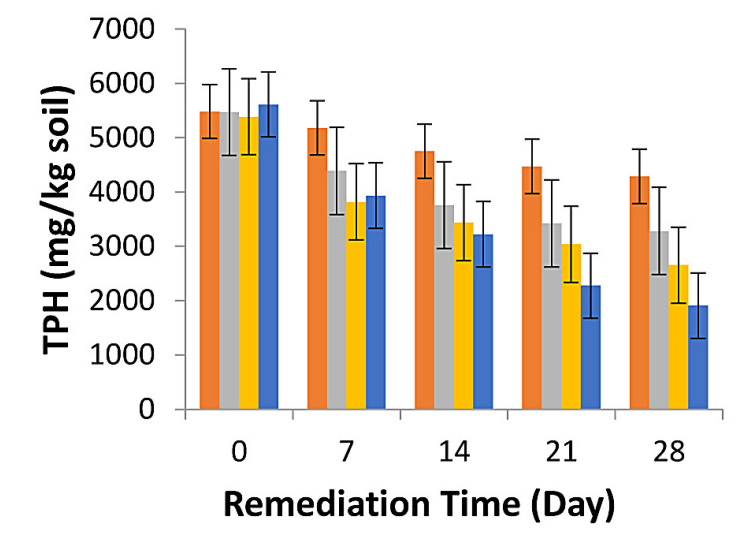

$\square$ Control (Natural Attenuation) $\square 20 \mathrm{~g} \square 30 \mathrm{~g} \square 40 \mathrm{~g}$

Figure 1. a - time course for TPH biodegradation in soil under the influence of varying particle sizes of CAC,

$\mathrm{b}$ - time course for TPH biodegradation in soil under the influence of varying CAC dosage.

Bars indicate the average of triplicate samples while the error bars show the standard deviation. 
for degrading organisms' growth [Vasilyeva et al., 2006]. Similar observations have been reported for the use of activated carbon in the biodegradation of herbicide propanil (3',4'-dichloropropionanilide) in the Krasnodar region of Russia, 3,4-dichloroaniline, polychlorinated biphenyls (PCB), 2,4,6-trinitrotoluene (TNT) [Vasilyeva et al., 2006; 2010], anthracene [Owabor and Aluyor, 2008], 2,6-dichlorophenol [Agarry et al., 2013b] and diesel fuel [Semenyuk et al., 2014]. Payne et al. [2011] also reported that addition of AC had a slight stimulatory effect on PCB dechlorination in sediment. Nevertheless, contrary observations on the effects of strong AC amendments on pollutant biodegradation processes have been reported. The addition of $\mathrm{AC}$ to contaminated soils was shown to reduce spiked ${ }^{14} \mathrm{C}$ phenanthrene metabolism to ${ }^{14} \mathrm{CO}_{2}$ in laboratory batch experiments. Karapanagioti et al. [2001] showed that slow sorption kinetics limited spiked phenanthrene biodegradation in sediment slurries containing coal particles.

Figure $2 \mathrm{a}$ and $2 \mathrm{~b}$ shows the degradation profile of WBLCO in soil as a function of remediation time for different particle sizes and dosage of biochar amendment, respectively.

Figure $2 \mathrm{a}$ revealed that the petroleum hydrocarbon degradation began during the first week of remediation time in all the treatments and slowly continued up to the fourth week (day 28). The TPH reduced correspondingly from 6454, 7105 and $7562 \mathrm{mg} / \mathrm{kg}$ soil (day 0) to 3590,3225 and $2642 \mathrm{mg} / \mathrm{kg}$ soil (day 28) which corresponds to $44.4 \%, 54.6 \%$ and $65.1 \%$ TPH degradation in soil amended with $0.48,0.07$ and $0.02 \mathrm{~mm}$ particle sizes of biochar, respectively. These observations indicate that petroleum hydrocarbon biodegradation in different biochar particle size amendedcontaminated soil increased with decrease in particle size. That is, percentage degradation of TPH in WBLCO contaminated soil was relatively higher for soil amended with smaller particle size of biochar.

The biodegradation profile of WBLCO in soil as a function of remediation time for 0.48 $\mathrm{mm}$ particle size of 20,30 and $40 \mathrm{~g}$ of plantain peel-biochar amendment, respectively (i.e. effect of biochar dosage), is shown in Figure 2b. It is observed that the biodegradation of TPH began during the first week of remediation time in all the treatments and this slowly continued up to the fourth week (day 28). The TPH reduced correspondingly from 6454,7221 and $7723 \mathrm{mg} / \mathrm{kg}$ soil (day 0) to 3590,3400 and $2430 \mathrm{mg} / \mathrm{kg}$ soil (day 28 ) corresponding to $44.4 \%, 53 \%$ and $68.5 \%$ TPH degradation in soil amended with 20, 30 and $40 \mathrm{~g}$ dosage of plantain peel-biochar, respectively. This observation indicates that degradation of petroleum hydrocarbons in WBLCO contaminated soil amended with different dosage of biochar increased with increase in dosage. That is, percentage TPH degradation was relatively higher for soil amended with higher dosage of biochar. Generally, it is observed from Figure $2 \mathrm{a}$ and $2 \mathrm{~b}$ that the soil amendment with biochar enhanced the petroleum hydrocarbon biodegradation in comparison with the unamended contaminated (a)

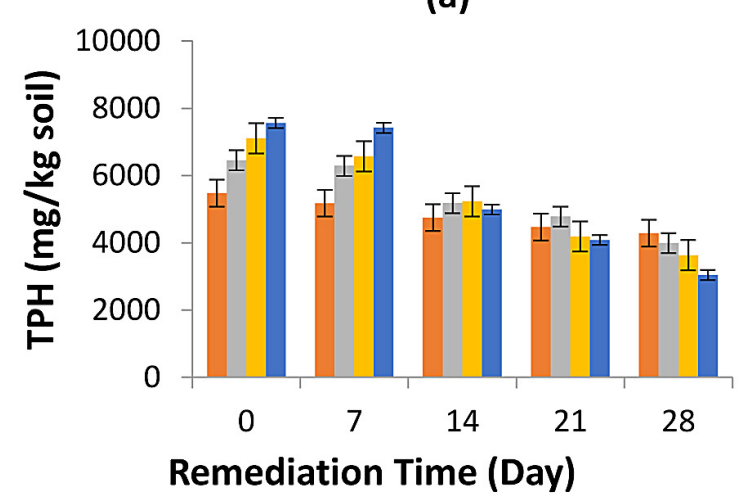

$\square$ Control (Natural Attenuation)
$\square 0.48 \mathrm{~mm}$
$\square 0.07 \mathrm{~mm}$
$\square 0.02 \mathrm{~mm}$

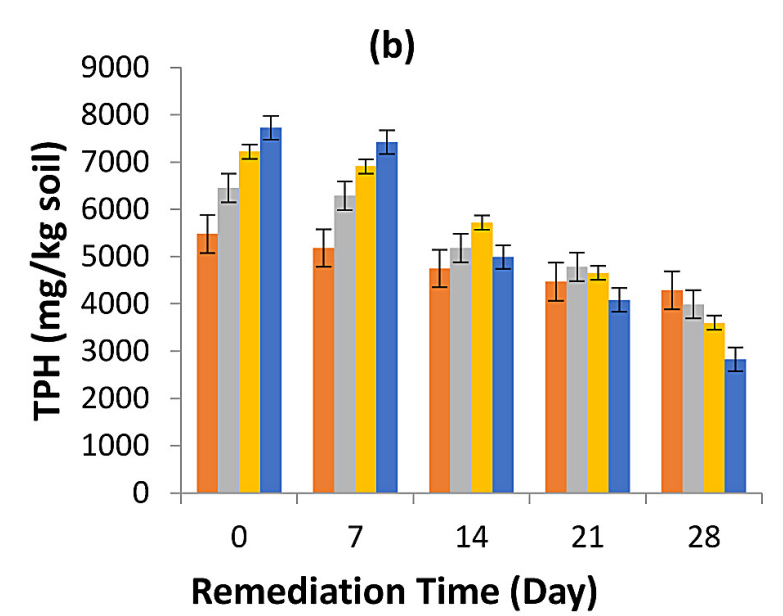

$\square$ Control (Natural Attenuation) $\square 20 \mathrm{~g} \square 30 \mathrm{~g} \square 40 \mathrm{~g}$

Figure 2. a - time course for TPH biodegradation in soil under the influence of varying particle sizes of biochar, $\mathrm{b}$ - time course for TPH biodegradation in soil under the influence of varying biochar dosage.

Bars indicate the average of triplicate samples while the error bars show the standard deviation 
soil (natural attenuation). Similar observations have been reported for the use of biochar in the biodegradation of polycyclic aromatic hydrocarbons [Beesley et al., 2010], volatile petroleum hydrocarbons [Bushnaf et al., 2011], total petroleum hydrocarbon [Qin et al., 2013], phenanthrene [Marchal et al., 2013] and 2,6-dichlorophenol [Agarry et al., 2013b]. This observation of enhanced petroleum hydrocarbon biodegradation may probably be due to the fact that biochar could have acted as an adsorbent in the soil as well as having a stimulatory effect by increasing nutrient availability (nitrogen, phosphorous and micronutrients) [Chan and $\mathrm{Xu}, 2009$; Park et al., 2011] and providing a habitat that favoured increased microbial activity [Thies and Rillig, 2009].

\section{Microbial growth}

Figures $3 \mathrm{a}-3 \mathrm{~d}$ shows the growth profiles of the total hydrocarbon degrading bacteria (THDB) in WBLCO contaminated soil amended with different particle sizes and dosage of CAC and plantain peel-biochar, respectively.

Generally, it is seen that the microbial (THDB) counts increased from Day 0 to Day 28 in each of the four treatment microcosms. For CAC-soil amended microcosms; the THDB count increased

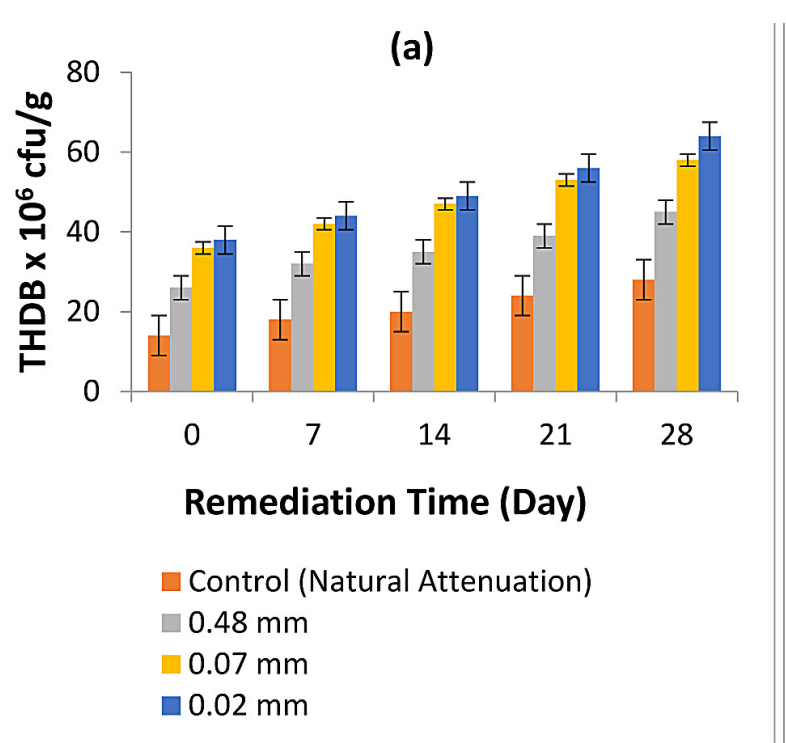

(b)

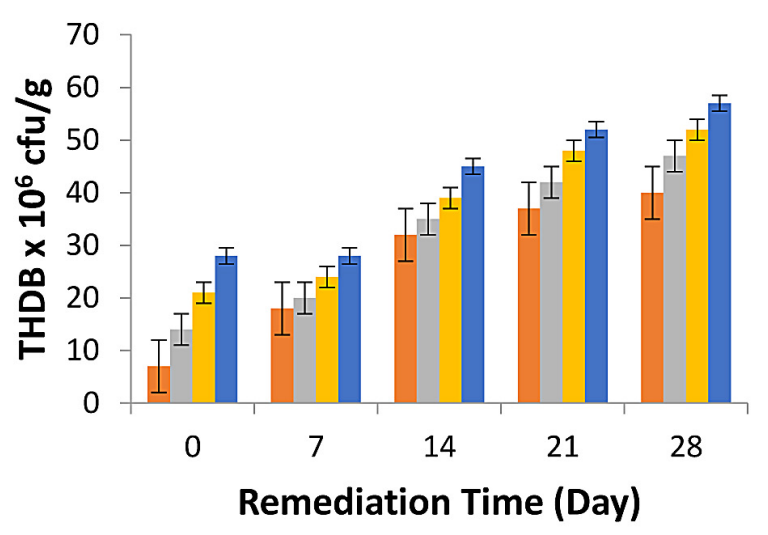

$\square$ Control (Natural Attenuation) $\square 20 \mathrm{~g} \square 30 \mathrm{~g} \square 40 \mathrm{~g}$
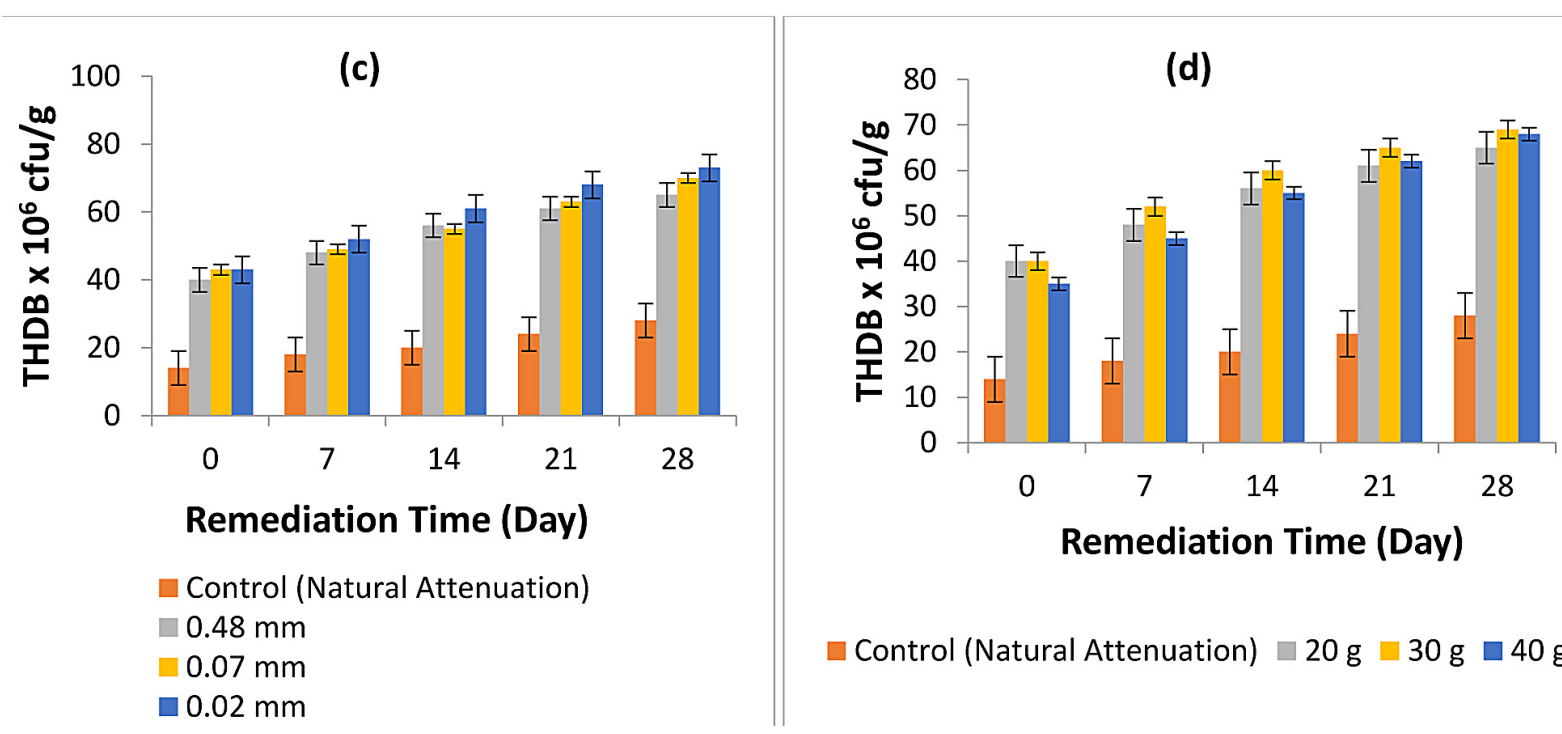

$\square$ Control (Natural Attenuation) $\square 20 \mathrm{~g} \square 30 \mathrm{~g} \square 40 \mathrm{~g}$

Figure 3. a - time course for the growth of total hydrocarbon degrading bacteria (THDB) under the influence of different CAC particle sizes, $b$ - time course for the growth of total hydrocarbon degrading bacteria (THDB) under the influence of different CAC dosage, $\mathrm{c}$ - time course for the growth of total hydrocarbon degrading bacteria (THDB) under the influence of different biochar particle sizes, $\mathrm{d}$ - time course for the growth of total hydrocarbon degrading bacteria (THDB) under the influence of different biochar dosage. Bars indicate the average of triplicate samples while the error bars show the standard deviation 
from 26 to $46 \times 10^{6} \mathrm{CFU} / \mathrm{g}$; 36 to $58 \times 10^{6} \mathrm{CFU} / \mathrm{g}$; and 38 to $64 \times 10^{6} \mathrm{CFU} / \mathrm{g}$ for $0.48 \mathrm{~mm}, 0.07 \mathrm{~mm}$ and $0.02 \mathrm{~mm}$ particle size of supplemented CAC, respectively (Figure $3 \mathrm{a}$ ) while it increased from 26 to $46 \times 10^{6} \mathrm{CFU} / \mathrm{g} ; 32$ to $52 \times 10^{6} \mathrm{CFU} / \mathrm{g}$; and 34 to $57 \times 10^{6} \mathrm{CFU} / \mathrm{g}$ for $20 \mathrm{~g}, 30 \mathrm{~g}$ and $40 \mathrm{~g}$ of supplemented CAC, respectively (Figure $3 b$ ). Thus, higher microbial counts were observed for microcosms with relatively smaller particle size of $\mathrm{CAC}$ as well as soil microcosm with higher dosage of CAC. For the unamended soil microcosm (natural attenuation), the THDB increased from 14 to $28 \times 10^{6} \mathrm{CFU} / \mathrm{g}$. This showed that the soil microcosms amended with CAC enhanced the microbial growth rate which accounted for the higher bacterial counts than the unamended soil microcosm (natural attenuation). Overall, these results show that CAC amendment was not detrimental to aerobic microbial activity. The higher microbial count in microcosms amended with CAC may be due to favourable conditions provided by the adsorbent in the soil which stimulated an increase in microbial population and activities, thus leading to high energy (carbon) demand by the hydrocarbon-degrading microorganisms. This has resulted in the increased reduction of the total petroleum hydrocarbon (TPH) in the remediation treatments. Similar observations have been reported [Vasilyeva et al., 2006; Meynet et al., 2012].

For biochar-soil amended microcosms; the THDB count increased from 40 to $65 \times 10^{6} \mathrm{CFU} / \mathrm{g}$; 43 to $70 \times 10^{6} \mathrm{CFU} / \mathrm{g}$; and 43 to $73 \times 10^{6} \mathrm{CFU} / \mathrm{g}$ for $0.48 \mathrm{~mm}, 0.07 \mathrm{~mm}$ and $0.02 \mathrm{~mm}$ particle size of supplemented biochar, respectively (Figure 3c) while it increased from 40 to $65 \times 10^{6} \mathrm{CFU} / \mathrm{g} ; 40$ to $69 \times 10^{6} \mathrm{CFU} / \mathrm{g}$; and 35 to $68 \times 10^{6} \mathrm{CFU} / \mathrm{g}$ for $20 \mathrm{~g}, 30 \mathrm{~g}$ and $40 \mathrm{~g}$ of supplemented biochar, respectively (Figure $3 \mathrm{~d}$ ). In the unamended soil microcosm (natural attenuation), the THDB increased from 14 to $28 \times 10^{6} \mathrm{CFU} / \mathrm{g}$. This revealed that the soil microcosms amended with biochar enhanced the microbial growth rate which accounted for the higher bacterial counts than the unamended soil microcosm (natural attenuation). Similar observations have been reported [Meynet et al., 2013]. Furthermore, it showed that relatively higher microbial counts were observed for microcosms amended with smaller particle size of plantain peel-biochar and higher dosage, respectively. The higher microbial count in microcosms with biochar amendment may be due to increased nutrient availability, microbial activity and improved aeration stimulated by the biochar presence [Park et al., 2011] which stimulated an increase in hydrocarbon degradation (utilization for carbon and energy) and thus resulted in higher microbial growth of the hydrocarbon-degrading microorganisms.

\section{Evaluation of biodegradation kinetics and half-life}

First-order kinetics model equation (Eq. 2) fitted to the biodegradation data (Figures $4 \mathrm{a}-4 \mathrm{~d}$ ) was used to determine the rate of TPH biodegradation in the various remediation treatments. The values of the rate constants obtained from fitting of the model are presented in Table 2.

The results in Table 2 as indicated by the high correlation determination $\left(R^{2}\right)$ showed that the biodegradation of TPH in WBLCO fitted well to the first-order kinetic model. The halflife time of TPH biodegradation was calculated using Eq. (3). The biodegradation rate constants $(k)$ and half-life times $\left(t_{1 / 2}\right)$ for the different remediation treatments are presented in Table 2. It is to be noted that the higher is the biodegradation rate constants, the higher or faster is the rate of biodegradation and consequently the lower is the half-life time. It could be seen from Table 2 that for CAC-soil amended microcosms, the soil microcosm amended with $0.02 \mathrm{~mm}$ particle size of CAC had a higher $k\left(0.034\right.$ day $\left.^{-1}\right)$ and lower $t_{1 / 2}$ (20.4 days) than that amended with $0.07 \mathrm{~mm}$ $\left(k=0.025\right.$ day $^{-1}$ and $t_{1 / 2}=27.7$ days $)$ and $0.48 \mathrm{~mm}$ particle size $\left(k=0.018\right.$ day $^{-1}$ and $t_{1 / 2}=38.5$ days $)$, respectively; while the soil microcosm amended with $40 \mathrm{~g}$ of CAC had a higher $k\left(0.037\right.$ day $\left.^{-1}\right)$ and lower $t_{1 / 2}$ (18.7 days) than that amended with 30 $\mathrm{g}\left(k=0.025\right.$ day $^{-1}$ and $t_{1 / 2}=27.7$ days $)$ and $20 \mathrm{~g}(k$ $=0.018$ day $^{-1}$ and $t_{1 / 2}=38.5$ days), respectively. For biochar-soil amended microcosms, the soil amended with $0.02 \mathrm{~mm}$ particle size of biochar had a higher $k\left(0.037\right.$ day $\left.^{-1}\right)$ and lower $t_{1 / 2}(18.7$ days $)$ than that amended with $0.07 \mathrm{~mm}(k=0.028$ day $^{-1}$ and $t_{1 / 2}=24.8$ days) and $0.48 \mathrm{~mm}$ particle size ( $k=0.021$ day $^{-1}$ and $t_{1 / 2}=33.0$ days), respectively; while the soil microcosm amended with $40 \mathrm{~g}$ of biochar had a higher $k\left(0.041\right.$ day $\left.^{-1}\right)$ and lower $t_{1 / 2}$ (16.9 days) than that amended with $30 \mathrm{~g}$ $\left(k=0.026\right.$ day $^{-1}$ and $t_{1 / 2}=26.7$ days $)$ and $20 \mathrm{~g}(k$ $=0.021 \mathrm{day}^{-1}$ and $t_{1 / 2}=33.0$ days), respectively. A biodegradation rate constant $(k)$ of 0.009 day $^{-1}$ and half-life time $\left(t_{1 / 2}\right)$ of 77.0 days was observed for the biodegradation of TPH in unamended-soil (natural attenuation). 
(a) Commercial Activated Carbon

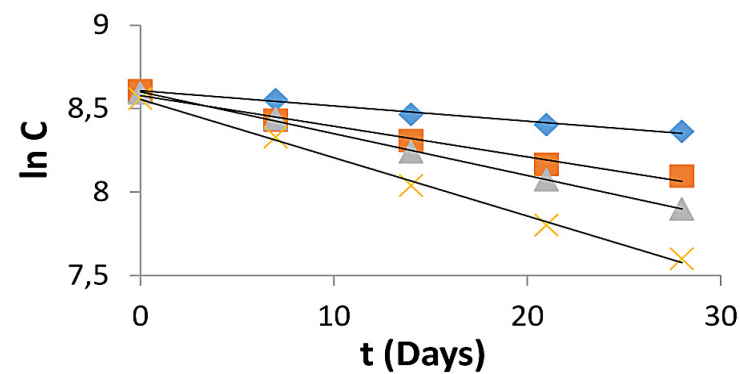

$\diamond$ Control (Natural Attenuation)

$0.48 \mathrm{~mm}$

$0.07 \mathrm{~mm}$

$0.02 \mathrm{~mm}$

- First-order kinetics

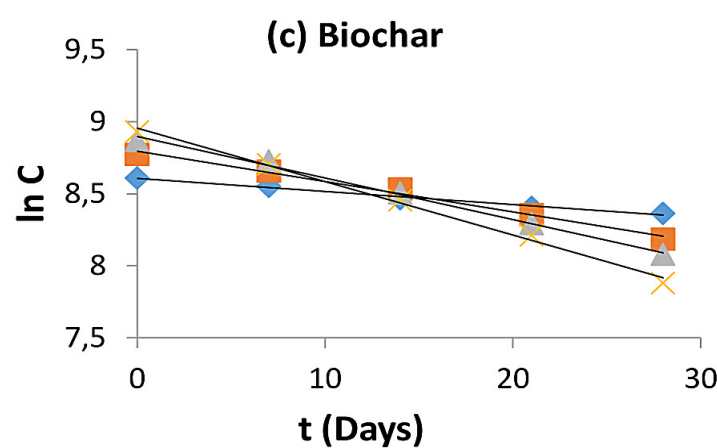

- Control (Natural Attenuation)

$0.48 \mathrm{~mm}$

$\Delta \quad 0.07 \mathrm{~mm}$

$0.02 \mathrm{~mm}$

First-order kinetics (b) Commercial Activated Carbon

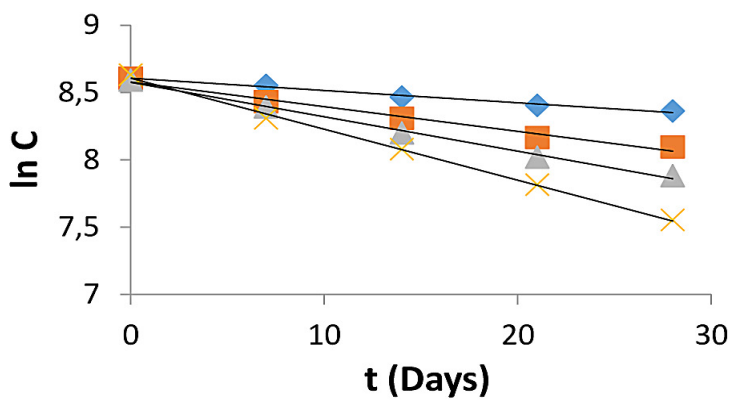

- Control (Natural Attenuation)

$\square 20 \mathrm{~g}$

$\triangle \quad 30 \mathrm{~g}$

$40 \mathrm{~g}$

_ First-order kinetics

(d) Biochar

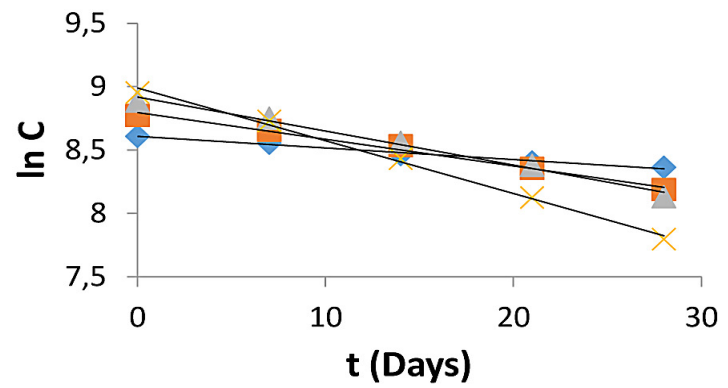

$\checkmark$ Control (Natural Attenuation)

$20 \mathrm{~g}$

$\triangle 30 \mathrm{~g}$

$40 \mathrm{~g}$

First-order kinetics

Figure 4. a - first-order kinetic model fitted to the biodegradation data of TPH under the influence of varying CAC particle sizes, $\mathrm{b}$ - first-order kinetic model fitted to the biodegradation data of TPH under the influence of varying CAC dosage, $\mathrm{c}$ - first-order kinetic model fitted to the biodegradation data of TPH under the influence of varying biochar particle sizes, $\mathrm{d}$ - first-order kinetic model fitted to the biodegradation data of TPH under the influence of varying biochar dosage

Table 2. First-order kinetic equation with correlation determination $\left(R^{2}\right)$ results of WBLCO biodegradation under the influence of commercial activated carbon and biochar

\begin{tabular}{|c|c|c|c|c|}
\hline Factors & First-Order Kinetic Equation & $k\left(\right.$ day $\left.^{-1}\right)$ & $R^{2}$ & Half-life $t_{1 / 2}$ (days) \\
\hline 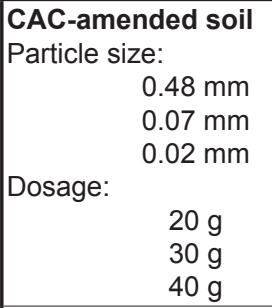 & $\begin{array}{l}C=-0,018 t+8,579 \\
C=-0,025 t+8,600 \\
C=-0,034 t+8,554 \\
C=-0,018 t+8,579 \\
C=-0,025 t+8,575 \\
C=-0,037 t+8,607\end{array}$ & $\begin{array}{l}0.018 \\
0.025 \\
0.034 \\
\\
0.018 \\
0.025 \\
0.037 \\
\end{array}$ & $\begin{array}{l}0.9820 \\
0.9980 \\
0.9960 \\
\\
0.9820 \\
0.9980 \\
0.9970 \\
\end{array}$ & $\begin{array}{l}38.5 \\
27.7 \\
20.4 \\
\\
38.5 \\
27.7 \\
18.7 \\
\end{array}$ \\
\hline 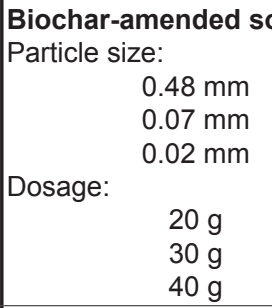 & $\begin{array}{l}C=-0,021 t+8,795 \\
C=-0,028 t+8,897 \\
C=-0,037 t+8,954 \\
C=-0,021 t+8,795 \\
C=-0,026 t+8,916 \\
C=-0,041 t+8,990\end{array}$ & $\begin{array}{l}0.021 \\
0.028 \\
0.037 \\
\\
0.021 \\
0.026 \\
0.041 \\
\end{array}$ & $\begin{array}{l}0.9900 \\
0.9940 \\
0.9940 \\
\\
0.9900 \\
0.9890 \\
0.9950 \\
\end{array}$ & $\begin{array}{l}33.0 \\
24.8 \\
18.7 \\
\\
33.0 \\
26.7 \\
16.9\end{array}$ \\
\hline $\begin{array}{l}\text { Unamended soil } \\
\text { (Natural attenuation) }\end{array}$ & $C=-0,009 t+8,607$ & 0.009 & 0.9870 & 77.0 \\
\hline
\end{tabular}




\section{Effectiveness of amendment agents}

A one-way ANOVA analysis was conducted to compare the biodegradation efficiency of the commercial activated carbon and biochar (amendment agents) and the result is presented in Table 3.

The result suggests that both the CAC and plantain peel-biochar (amendment agents) had a statistically significant effect on the biodegradation of WBLCO in soil at the $5 \%$ probability level $(\mathrm{p}=$ 0.05 ). The effectiveness of each amendment agents was therefore tested. Through evaluation of unamended soil microcosm (natural attenuation) and amended soil microcosm, the bioremediation efficiency $(\% \mathrm{E})$ was calculated at the end of 28 - day remediation period using Eq. (5) [Zahed et al., 2011]:

$$
\% \mathrm{E}=\frac{\% T P H_{(S)}-\% T P H_{(U)}}{\% T P H_{(S)}} \times 100
$$

where: $\% T P H_{(S)}$ - the removal of crude oil in the amended soil,

$\% T P H_{(V)}-$ the removal of crude oil in the unamended soil.

The results of E (\%) are illustrated in Table 4. The results generally showed that the efficiency of the CAC and biochar in stimulating TPH reduction (biodegradation) are relatively close. Thus, post hoc comparisons using Tukey's (HSD) test at $5 \%$ probability level were carried out to actually determine the significant difference in biodeg- radation efficiency between the two amendment agents. The difference in TPH concentration mean between pairs of treatments were greater than the HSD value, hence, the grouping of \%TPH mean using the Tukey's test for the two different treatments as presented in Table 5 shows that there is a significant difference in the bioremediation efficiency of $\mathrm{CAC}$ and biochar. All the treatments show a significantly different biodegradation rate among them. That is, the Tukey's test revealed that there are significant differences in the bioremediation efficiency between the control (natural attenuation), CAC and plantain peel-biochar. It also indicates that there is a significant difference in the bioremediation efficiency between the CAC and plantain peel-biochar. Therefore, between the two different amendment agents, plantain peelbiochar suggests to be relatively more effective with higher \% $\mathrm{E}(60.6 \%)$ than $\mathrm{CAC}(58.3 \%)$.

\section{CONCLUSIONS}

The present studies confirm that the use of $\mathrm{CAC}$ and plantain peel-biochar improved the rate of biodegradation in microcosms simulating soil or land environments contaminated with crude oil. At the end of 28 days remediation period, the maximum total petroleum hydrocarbon (TPH) removal that ranged from $40 \%$ to $61.6 \%$ and $40 \%$ to $66 \%$ was obtained for crude oil-contaminat-

Table 3. Analysis of variance (ANOVA) for the different treatments

\begin{tabular}{|c|c|c|c|c|c|}
\hline Source & Sum of squares & Degree of freedom & Mean of squares & F-value & $P$-value \\
\hline Treatment & 2700.6 & 2 & 1350.3 & 4784.7 & $2.39 \mathrm{E}-14$ \\
Error & 2.54 & 9 & 0.2822 & & \\
Total & 2703.14 & 11 & & & \\
\hline
\end{tabular}

Table 4. Percentage degradation of crude oil and bioremediation efficiency of amendment agent at the end of four weeks

\begin{tabular}{|c|c|c|}
\hline Amended-soil treatment & TPH degradation (mean) (\%) & E (\%) \\
\hline CAC & $52.3^{*} \pm 0.79$ & 58.3 \\
\hline Biochar & $55.3^{*} \pm 0.32$ & 60.6 \\
\hline Unamended soil (natural attenuation) & $1.8 \pm 0.34$ & - \\
\hline
\end{tabular}

* Mean of \%TPH degradation at 20,30 and $40 \mathrm{~g}$ dosage of amendment agents.

Table 5. Grouping of TPH mean for the different treatments computed by Tukey's method

\begin{tabular}{|c|c|c|c|}
\hline Treatments & TPH Mean (\%) & Standard error & Remarks \\
\hline Control (natural attenuation) & $21.8^{\mathrm{A}}$ & 0.171 & significant difference \\
\hline CAC & $52.3^{\mathrm{B}}$ & 0.397 & significant difference \\
\hline Biochar & $55.3^{\mathrm{C}}$ & 0.158 & significant difference \\
\hline
\end{tabular}

Means that do not share the same letter are significantly different. 
ed soil amended with different particle sizes of CAC $(0.02-0.48 \mathrm{~mm})$ and different amount of CAC dose, respectively. Also, TPH removal that ranged from $44.4 \%$ to $65.1 \%$ and $44.4 \%$ to $67.8 \%$ was obtained for soil amended with different particle sizes of biochar $(0.02-0.48 \mathrm{~mm})$ and different amount of biochar dose, respectively.

The biodegradation rate constant obtained from the application of first order kinetics described the rate of crude oil biodegradation in soil with and without amendment. The rate constant $(k)$ ranges between 0.018 day $^{-1}$ and 0.037 day $^{-1}$ for CAC-amended soil microcosm as well as between 0.021 day $^{-1}$ and 0.041 day $^{-1}$ for biochar-amended soil microcosm and 0.009 day $^{-1}$ for unamended soil microcosm (natural attenuation). A half-life time $\left(t_{1 / 2}\right)$ of 77 days was observed for biodegradation of crude oil in soil not amended with CAC or biochar. This was reduced to between 18.7 and 16.9 days with the usage of different dosage and particle sizes of CAC and biochar, respectively. Statistical analysis using ANOVA to determine significance effect of the amendment agents on WBLCO biodegradation showed that WBLCO biodegradation in soil was highly influenced by the addition of CAC and plantain peel-biochar as amendment agents, respectively.

Statistical analysis using ANOVA and Tukey's test to determine significance effect of the amendment agents on WBLCO biodegradation also showed that WBLCO biodegradation in soil was highly influenced by the CAC and plantain peel-biochar. There was a significant difference in the bioremediation efficiency of the CAC and plantain peel-biochar. From the bioremediation efficiency (\% E) and biodegradation rate constant $(k)$ values, the bioremediation performance of plantain peel-biochar was relatively better than that of CAC. Amendment of soils with biochar has the potential to be an inexpensive, relatively novel strategy to mitigate the risk of organic compound contamination and exposure in soils.

The bioremediation technique proposed here for soils contaminated with crude oil and other lighter oil distillates could be suitable in field, because of its low costs and its low environmental risk associated with volatile hydrocarbon losses. Nevertheless, these findings do not represent a general rule and site-specific studies are needed, the approach used here can be a relevant support tool when designing bioremediation strategies on site.

\section{REFERENCES}

1. Adams R.H., Guzmán-Osorio F.J. 2008. Evaluation of land farming and chemico-biological stabilization for treatment of heavily contaminated sediments in a tropical environment. Int. J. Environ. Sci. Technol. 5 (2), 169-178.

2. Adesodun J.K., Mbagwu J.S.C. 2008. Biodegradation of waste-lubricating petroleum oil in a tropical alfisol as mediated by animal droppings.Bioresource Technol., 99 (13), 5659-5665.

3. Agarry S.E., Ogunleye O.O. 2012. Box-behnken designs application to study enhanced bioremediation of soil artificially contaminated with spent engine oil using biostimulation strategy. Int. J. Energy and Environ. Eng. 3, 31-34.

4. Agarry S.E., Aremu M.O. 2012. Batch equilibrium and kinetic studies of simultaneous adsorption and biodegradation of phenol by pineapple peels immobilized Pseudomonas aeruginosa NCIB 950, British Biotechnol. J. 2, 26-48.

5. Agarry S.E., Aremu M.O., Aworanti O.A. 2013a. Kinetic modelling and half-life study on bioremediation of soil co-contaminated with lubricating motor oil and lead using different bioremediation strategies. Soil and Sediment Contam. an Int. J. 22 (7), 800-816.

6. Agarry S.E., Aremu M.O. Aworanti O.A. 2013b. Biodegradation of 2, 6-dichlorophenol wastewater in soil column reactor in the presence of pineapple peels-derived activated carbon, palm kernel oil and inorganic fertilizer. J. Environ. Protection, 4, 537-547.

7. Amanchukwu C., Obafemi C.A., Okpokwasili, G.C. 1989. Hydrocarbon degradation and utilization by a palmwine yeast isolate. FEMS Microbiology Letters 57, 51-54.

8. Aronson D., Boethling R., Howard P., Stiteler, W. 2006. Estimating biodegradation half-lives for use in chemical screening. Chemosphere 63, 1953-1960.

9. Beesley L., Moreno-Jimenez E., Gomez-Eyles, J.L. .2010. Effects of Biochar and greenwaste compost amendments on mobility, bioavailability and toxicity of inorganic and organic contaminants in a multi-element polluted soil. Environ. Poll., 158, 2282-2287.

10. Bejarano A.C., Michel J. 2010. Large-scale risk assessment of polycyclic aromatic hydrocarbons in shoreline sediments from Saudi Arabia: environmental legacy after twelve years of the Gulf war oil spill. Environ. Poll., 158, 1561-1569.

11. Bremner J.M., Mulvaney C.S. 1982. Total nitrogen determination. In: A.L. Page, R.H. Miller, D.R. Keeney (Eds) Method of Soil Analysis, Vol. 2. Madison, WI: American Society of Agronomy, pp. 595.

12. Bushnaf K.M., Puricelli S., Saponaro S., Werner D. 2011. Effect of biochar on the fate of volatile 
petroleum hydrocarbons in an aerobic sandy soil. J. Contam. Hydrol., 126, 208-215.

13. Chan K.Y., Xu Z., 2009. Biochar: nutrient properties and their enhancement. In: Lehmann J., Joseph S. (Eds.), Biochar for Environmental Management: Science and Technology. Earthscan, London, pp. 67-84.

14. Fouépé T.A., Kengni T.L., Gurunadha Rao V.V.S., Ndam N.J.R. 2009. Transfer of moisture through the unsaturated zone in the tropical forest using the neutron probe. Int. J. Environ. Sci. Technol. 6 (3), 379-388.

15. Ghosh U., Luthy R.G., Cornelissen G., Werner D., Menzie C.A. 2011. In-situ sorbent amendments: A new direction in contaminated sediment management. Environ. Sci. Technol., 45, 1163-1168.

16. Glaser B., Haumaier L., Guggenberger G., Zech W., 2001. The 'Terra Preta' phenomenon: a model for sustainable agriculture in the humid tropics. Naturwissenschaften $88,37-41$.

17. Hale S.E., Lehmann J., Rutherford D., Zimmerman A.R., Bachmann R.T., Shitumbanuma V., O’Toole A., Sundqvist K.L., Arp H.P.H., Cornelissen G. 2012. Quantifying the total and bioavailable polycyclic aromatic hydrocarbons and dioxins in biochars. Environ. Sci. Technol., 46, 2830-2838.

18. Ikhajiagbe B., Anoliefo G.O. 2011. Natural attenuation of a 14-month-old waste engine oil polluted soil. J. Soil Sci. Environ. Manage., 2(7), 184-192.

19. Jakob L., Hartnik T., Henriksen T., Elmquist M., Brändli R.C., Hale S.E., Cornelissen G., 2012. PAH-sequestration capacity of granular and powder activated carbon amendments in soil, and their effects on earthworms and plants. Chemosphere 88, 699-705.

20. Karapanagioti H.K., Gossard C.M., Strevett K.A., Kolar R.L., Sabatini D.A. 2001. Model coupling intraparticle diffusion/sorption, nonlinear sorption, and biodegradation processes. J. Contam. Hydrol., $48,1-21$.

21. Kuhan R.C., Gupta R. 2009. Biological remediation of petroleum contaminate. In: A. Singh R.C. Kuhan O.P. Ward (Eds.), Soil Biology, Advances in Applied Bioremediation, Springer-Verlag, Berlin/ Heidelberg, pp. 73-186.

22. Laird D.A. 2008. The charcoal vision: a win ewinewin scenario for simultaneously producing bioenergy, permanently sequestering carbon, while improving soil and water quality. Agronomy J., 100, 178-181.

23. Langlois V., Rutter A., Zeeb B., 2011. Activated carbon immobilizes residual polychlorinated biphenyls in weathered contaminated soil. J. Environ. Qual. 40, 1130-1134.

24. Lehmann, J. 2007. A handful of carbon. Nature, $447,143-144$.
25. Lehmann J., Joseph S. 2009. Biochar for Environmental Management. 1st ed.; Lehmann, J., Ed.; Earthscan: London, UK, pp. 1-9.

26. Less Z.M., Senior E. 1995. Bioremediation. A practical solution to land pollution. In: Clean Technology and the Environment, Chapman and Hall, New York, pp. 121-146.

27. Liang B., Lehmann J., Solomon D., Kinyangi J., Grossman J., O’Neill B., Skjemstad J.O., Thies J., Luizao F.J., Petersen J., Neves E.G. 2006. Black carbon increases cation exchange capacity in soils. Soil Science Society of America Journal 70, 1719-1730.

28. Liang B.Q., Lehmann J., Sohi S.P., Thies J.E., O’Neill B., Trujillo L., Gaunt J., Solomon D., Grossman J., Neves E.G., Luizao F.J. 2010. Black carbon affects the cycling of non-black carbon in soil. Organic Geochemistry 41, 206-213.

29. Mandri T., Lin J. 2007. Isolation and characterization of engine oil degrading indigenous microorganisms in Kwazulu-Natal, South Africa. Afri. J. Biotechnol., 6 (1), 23-27.

30. Marchal G., Smith K.E.C., Rein A., Winding A., Trapp S., Karlson U.G. 2013. Comparing the desorption and biodegradation of low concentrations of phenanthrene sorbed to activated carbon, biochar and compost. Chemosphere, 90, 1767-1778.

31. Marris E., 2006. Putting the carbon back: black is the new green. Nature 442, 624-626.

32. Matthies M., Witt J., Klasmeier J. 2008. Determination of soil biodegradation half lives from simulation testing under aerobic laboratory conditions: a kinetic model approach. Environ. Poll., 156, 99-105.

33. McLean E.O. 1982. Soil pH and lime requirement In: C.A. Black (Ed.) Methods in Soil Analysis: Chemical and Microbiological Properties, Part II, Madison, WI American Society of Agronomy.

34. Meynet P., Hale S.E., Davenport R.J., Cornelissen G., Breedveld G.D., Werner D. 2012. Effect of activated carbon amendment on bacterial community structure and functions in a PAH impacted urban soil. Environ. Sci. Technol. 46, 5057-5066.

35. Mukhin V.M., Dubonosov V.T., Shmelev S.I. 1995. Application of active carbons for detoxification of soils contaminated with pesticide residues. Russian Chem. J., 6, 135-138.

36. Nelson D.W., Sommers L.E. 1982. Determination of organic carbon. In: A.L. Page, R.H. Miller, and D.R. Keeney (Eds.) Method of soil analysis. Madison, WI: American Society of Agronomy, pp 539.

37. Novak J.M., Busscher W.J., Watts D.W., Laird D.A., Ahmedna M.A., Niandou M.A.S. 2010. Short-term $\mathrm{CO}_{2}$ mineralization af ter additions of biochar and switchgrass to a typic kandiudult. Geoderma 154, 281-288. 
38. O’Neill B., Grossman J., Tsai M.T., Gomes J.E., Lehmann J., Peterson J., Neves E., Thies J.E., 2009. Bacterial community composition in Brazilian Anthrosols and adjacent soils characterized using culturing and molecular identification. Microbial Ecology 58, 23-35.

39. Okoh A.I. 2006. Biodegradation alternative in the cleanup of petroleum hydrocarbon pollutants. Biotechnol. Molecular Biol. Rev., 1, 38-50.

40. Olsen S.R., Sommers L.E. 1982. Determination of available phosphorus. In: A.L. Page, R.H. Miller, D.R. Keeney (Eds.) Method of Soil Analysis. Madison, WI: American Society of Agronomy, pp 403.

41. Orshansky F., Narkis N. 1997. Characteristics of organics removal by PACT simultaneous adsorption and biodegradation. Wat. Res. 31(3), 391-398.

42. Osuji L.C., Egbuson E.J.G., Ojinnaka C.M. 2005. Chemical reclamation of crude-oil-inundated soils from Niger Delta, Nigeria. Chem. Ecol., 21(1), 1-10.

43. Owabor C.N., Aluyor E.O. 2008. Application of adsorbent as a novel technique during biodegradation of a polycyclic aromatic hydrocarbon (anthracene). Afri. J. Biotechnol., 7(18), 3321-3325.

44. Park J.H., Choppala G.K., Bolan N.S., Chung J.W., Chuasavathi T. 2011. Biochar reduces the bioavailability and phytotoxicity of heavy metals. Plant Soil 348, 439-451.

45. Payne R.B., May H.D., Sowers K.R. 2011. Enhanced reductive dechlorination of polychlorinated biphenyl impacted sediment by bioaugmentation with a dehalorespiring bacterium. Environ. Sci. Technol., 45 (20), 8772-8779.

46. Qin G., Gong D., Fan M-Y. 2013. Bioremediation of petroleum-contaminated soil by biostimulation amended with biochar. Int. Biodeter. \& Biodegrad., $85,150-155$.

47. Semenyuk N.N., Yatsenko V. ., Strijakova E.R., Filonov A.E., Petrikov K.V., Zavgorodnyaya Y.A., Vasilyeva G.K. 2014. Effect of activated charcoal on bioremediation of diesel fuel-contaminated soil. Microbiol., 83 (5), 589-598.

48. Sinkkonen S., Paasivirta J. 2000. Degradation halflife times of PCDDs, PCDF sand PCBs for environmental fate modeling. Chemosphere 40, 943-949.

49. Sohi S., Krull E., Lopez-Capel E., Bol R. 2010. A review of biochar and its use and function in soil. Adv. Agronomy 105, 47-82.

50. Solomon D., Lehmann J., Thies J., Schafer T., Liang B.Q., Kinyangi J., Neves E., Petersen J., Luizao F., Skjemstad J. 2007. Molecular signature and sources of biochemical recalcitrance of organic $\mathrm{C}$ in Amazonian Dark Earths. Geochimica et Cosmochimica Acta 71, 2285-2298.

51. Sparrevik M., Saloranta T., Cornelissen G., Eek E., Fet A.M., Breedveld G.D., Linkov I. 2011. Use of life cycle assessments to evaluate the environmental footprint of contaminated sediment remediation. Environ. Sci. Technol. 45, 4235-4241.

52. Spokas K.A., Koskinen W.C., Baker J.M., Reicosky D.C. 2009. Impacts of woodchip biochar additions on greenhouse gas production and sorption/degradation of two herbicides in a Minnesota soil. Chemosphere, 77, 574-581.

53. Strek H.J., Weber J.B., Shea P.J., Mrozek Jr. E., Overcash M.R. 1981. Reduction of polychorinated biphenyl toxicity and uptake of carbon-14 activity by plants through the use of activated carbon, J. Agr. Food Chem., 29, 288-293.

54. Thies J.E., Rillig M.C. 2009. Characteristics of biochar: Biological properties. In: Lehmann J., Joseph S. (Eds.) Biochar for Environmental Management. Earthscan: London, UK, pp. 85-105.

55. Van Zwieten L., Kimber S., Morris S., Chan K.Y., Downie A., Rust J., Joseph S., Cowie A. 2010. Effects of biochar from slow pyrolysis of papermill waste on agronomic performance and soil fertility. Plant and Soil 327, 235-246.

56. Vasilyeva G.K., Strijakova E.R., Shea P.J. 2006. Use of activated carbon for soil bioremediation. Soil and Water Pollution Monitoring, Protection and Remediation, 309-323.

57. Vasilyeva G.K., Strijakova E.R., Nikolaeva S.N., Lebedev A.T., Shea P.J. 2010. Dynamics of PCB removal and detoxification in historically contaminated soils amended with activated carbon. Environ. Pollut., 158, 770-777.

58. Vidali M. 2001. Bioremediation: An overview. J. Appl. Chemistry 73(7), 1163-1172.

59. Xu T., Lou L., Luo L., Cao R., Duan D., Chen Y. 2012. Effect of bamboo biochar on pentachlorophenol leachability and bioavailability in agricultural soil. Science of the Total Environment 414, 727-731.

60. Yerushalmi L., Rocheleau S., Cimpoia R., Sarrazin M., Sunahara G., Peisajovich A., Leclair G., Guiot R.S. 2003. Enhanced bioremediation of petroleum hydrocarbons in contaminated soil, Bioremediation J., 7 (1), 37-51.

61. Yeung P.Y., Johnson R.L., Xu J.G. 1997. Biodegradation of petroleum hydrocarbons in soil as affected by heating and forced aeration. J. Environ. Quality 26, 1511-1576.

62. Zahed M.A., Abdul Aziz H., Isa M.H., Mohajeri L., Mohajeri S., Kutty S.R.M. 2011. Kinetic modeling and half life study on bioremediation of crude oil dispersed by Corexit 9500. J. Hazard. Mater., 185, 1027-1031.

63. Zimmerman A.R., Gao B., Ahn M-Y. 2011. Positive and negative carbon mineralization priming effects among a variety of biochar-amended soils. Soil Biol. \& Biochem., 43, 1169-1179. 